\title{
LÉPÉSEK A KORSZERŰ FÖLDRAJZOKTATÁS FELÉ: EGY PROBLÉMAORIENTÁLT OKTATÁSI LEHETŐSÉGEKET ÉS DIGITÁLIS TECHNOLÓGIAI ÚJITTÁSOKAT KÍNÁLÓ ESZKÖZFEJLESZTÉS EREDMÉNYEI
}

\author{
STEPS TOWARDS MODERN GEOGRAPHY EDUCATION: \\ RESULTS OF A DEVELOPMENT OFFERING PROBLEM-ORIENTED \\ EDUCATIONAL OPPORTUNITIES AND IT INNOVATIONS
}

\author{
Farsang Andrea \\ DSc, egyetemi tanár, Szegedi Tudományegyetem Természettudományi és Informatikai Kar \\ Természeti Földrajzi és Geoinformatikai Tanszék, Szeged \\ farsang@geo.u-szeged.hu
}

ÖSSZEFOGLALÁS

Az MTA-SZE Földrajz Szakmódszertani Kutatócsoportunk fő célja egy problémaorientált oktatási lehetőségeket és digitális technológiai újításokat kínáló eszközfejlesztés révén a földrajzoktatás módszertani megújításának segítése. A fejlesztendő oktatási segédeszközök olyan a 8-13. évfolyamok számára alkalmazható, Magyarország egyes kis/közép tájainak, városainak földrajzát feldolgozó tanulói segédanyagok, amelyek a tanárok számára lehetővé teszik Magyarország általuk kiválasztott részleteinek problémacentrikus feldolgozását, s mintául szolgálnak más tananyagrészek hasonló módszertani megközelítésére.

Fontos feladat a kidolgozott eszközök tesztelése a pályázathoz csatlakozott általános és középiskolák oktatási gyakorlatában. Hogy minél pontosabban meg tudjuk határozni a fejlesztett eszköz előnyeit a hagyományos oktatáshoz képest, 2019 tavaszán hat általános iskola bevonásával kísérleti és kontrollcsoportos mérést szerveztünk Magyarország témakörének tanításához kapcsolódóan (8. osztály). A kísérleti oktatásban (ahol az általunk fejlesztett munkáltató lapok bevonásával zajlott a tanítás) 115 fő vett részt, a kontrollcsoportokban 151 tanuló. Ún. bemeneti és kimeneti feladatlapokat szerkesztettünk, melyek kitöltésével mérhetők a kísérleti csoport és a kontrollcsoport tanulási eredményességében beállt különbségek. Összességében a teljes teszten a kísérleti csoport átlaga szignifikánsan magasabb lett ( $t=3,56 ; p<0,001)$, a kísérleti hatás nagyságát kifejező éta négyzet értéke pedig 5,3\%, ami a pedagógiai kísérletek hatékonyságvizsgálatának hagyományos mérföldkövei szerint közepes kísérleti hatást jelez.

Az utóbbi évek megváltozott igényeihez alkalmazkodva a kutatócsoport tevékenységében új perspektívaként és törekvésként jelent meg az elkészített anyagok digitális tananyagként, online térben való alkalmazhatóságának vizsgálata. Az elmúlt évben egy munkáltató lap (Balaton - az ezerarcú magyar tenger) vonatkozásában minta online alkalmazást készítettünk, amely lehetővé teszi, hogy a tanulók egy virtuális térben kalandozva, az egyes információkat, interaktív feladatokat tetszőleges sorrendben felfüzve haladjanak az adott témakör élményszerű megismerésével. 


\section{ABSTRACT}

The overall aim of the MTA-SZTE Research Group on Geography Teaching and Learning is to help the methodological renewal of geography education by introducing problem-oriented teaching techniques and developing digital technological innovations to be used in class. We intend to develop a complete set of teaching aids that focus on the geography of certain microand mesoregions as well as towns and cities in Hungary. The set is recommended to be used by Grade- 8 to Grade-13 students and their teachers; it includes a teacher's resource book and individual student worksheets, all of which serve as useful tools to plan a geography lesson or a whole teaching unit concerning Hungary or a part of Hungary. The set employs a problem-centred approach to teaching and learning and it encourages the use of different techniques, which may also be applied to other parts of the geography curriculum.

Testing our educational tool with the help of the participating primary and secondary schools is an important task. To determine the benefits of the developed tool over traditional education as accurately as possible, we conducted an experimental and control group study with six elementary schools in the spring of 2019, when, according to the geography curriculum, the main topic of the lessons was Hungary (Grade 8). 115 students took part in the experimental group (here the participating teachers used our worksheets) and 151 students in the control groups. We employed pretest-posttest designs to measure the differences in learning outcomes between the groups. In conclusion, the mean of the experimental group in the overall test was significantly higher $(t=3.56 ; p<0.001)$, and the Eta-squared value representing the experimental effect size was 5.3\%, indicating a moderate experimental effect according to the traditional milestones in pedagogical experimentation.

The changing educational needs of the recent years led to the inclusion of new methods and tools. Our research group decided to study whether and how the prepared materials can be used in virtual reality, which would offer individual students, classes, and teachers alike to be immersed in an online space that allows the use of up-to-date and easily accessible learning materials. We created a sample online application for a worksheet (Balaton - The Thousand Faces of the Hungarian Sea), which allows students to wander through a virtual space, completing interactive tasks and reading various pieces of information in any preferred order, while learning about the topic through their virtual experiences.

Kulcsszavak: földrajzoktatás, problémaalapú tanítás, Magyarország földrajza

Keywords: geography teaching, problem-oriented teaching, geography of Hungary

Tanítási gyakorlatunk gyakran a megszokott tartalmi, módszertani sémákon alapul. Igaz ez mind a már több évtizede tanító, mind a friss diplomával rendelkezö, a közoktatásban dolgozó földrajz szakos kollégákra is. Ugyanakkor évek óta érzékelhető, hogy a tartalmi, tantervi változások, a digitális taneszközök térhódítása, valamint a tudással kapcsolatos társadalmi igények változása (hogy csak néhányat említsünk a külső kényszerítő körülmények közül) új kihívások elé állítják a közoktatásban dolgozó kollégákat és a jövő földrajztanárait. Napjainkban a lexikális ismeretek túlsúlya helyett a gyakorlati életben is alkalmazható földrajzi ismeretek készségszintủ elsajátítása vált hangsúlyossá, és ezzel párhuzamosan 
egyre erőteljesebb az igény a földrajztanárok módszertani kultúrájának megújulására is (Kádár-Farsang, 2017; Kádár et al., 2018).

Felméréseink szerint a hazai földrajztanítás egyik legnagyobb problémája a tanulók jó elméleti tudása és annak gyakorlati alkalmazhatósága közötti szakadék. Tanítási gyakorlatunk nem reagált arra a több tíz éve zajló folyamatra, mely során jelentősen megváltozott az értékes tudás fogalma (Csapó, 2002; Csapó, 2004). A minőségi, alkalmazható tudás az alkalmazásra képtelen, passzív ismereteket tartalmazó tudással szemben társadalmi, gazdasági értékké vált.

Napjaink földrajztanárainak egyik fö feladata, hogy felkészítsék tanulóikat a hagyományos és digitális tömegkommunikációs eszközökből és egyéb forrásokból származó információ befogadására, szelektálására és rendszerezésére, értékelésére, a világban végbemenő változások nyomon követésére. Mindezen tudáselemek kialakítására nagyon jó lehetőség a problémaalapú tanítás és tanulás (Problem Based Learning, PBL), melynek fő sajátossága egy olyan tanulási környezet, amelyben a tanulás hajtóerejét maga a probléma testesíti meg (Allen et al., 1996; M. Császár et al., 2018). A tanulók a probléma megoldásához szükséges információk megtanulása előtt ismerkednek meg a problémával, s nem az elsajátított tudás gyakorlása céljából kell különböző életszerủ problémákat megoldaniuk. A problémaközpontú tanulás fontos hozadéka, hogy hatására a tanulók kritikai, analitikus és kreatív gondolkodása is fejlődik. Egy-egy probléma megoldásán a diákok dolgozhatnak csoportokban, de lehetséges egyéni kutatási feladatok formájában is (Arts et al., 2002). Vagyis a PBL során összekapcsolható a kooperatív tanulás, a projektmunka, az IKT (Információs Kommunikációs Technológia) és a kutatásalapú tanulás is.

A földrajzoktatásunkban mindehhez alapvető módszertani megújulásra és szemléletváltásra van szükség (Probáld et al., 2015). A leszűkült időkereteket is figyelembe véve a földrajztanítás csak akkor lehet sikeres és eredményes, ha másként, más szemléletmód alapján és más módszerek előtérbe helyezésével valósul meg, mint a korábbi időszakban. E kihívásokhoz kell megtalálnunk a leghatékonyabb módszertani eljárásokat. Arra például nem lesz lehetőség, hogy a hagyományos részletességgel és tematikával a kontinensek valamennyi jelentősebb országát vagy éppen Magyarország valamennyi tájegységét, városát megismerjék a diákok. Csupán arra van mód, hogy jellemző, tipikus természeti és társadalmi-gazdasági jelenségekkel foglalkozzunk, éppen ezért ki kell alakítani a tanulókban a modellekben való gondolkodás képességét (Farsang, 2011). Fel kell azonban ismernünk, hogy a modern kooperatív, felfedezö, kutató feldolgozást lehetővé tevő módszerek elterjedését nagyban hátráltatja a jelenleg érvényben lévő kerettanterv témaköreinek modern szemléletủ oktatását támogató, esettanulmányokra épülő tanári kézikönyvek, módszertani segédanyagok hiánya.

2016-ban a Szegedi (SZTE) és a Pécsi Tudományegyetem (PTE), a Debreceni Egyetem (DE), az Eötvös Loránd Tudományegyetem (ELTE), valamint az Oktatáskutató és Fejlesztő Intézet (OFI) kutatóiból és a közoktatásban dolgozó tanárokból 
az MTA támogatásával megalakult az MTA Földrajz szakmódszertani kutatócsoport (URL1). Fő célkitűzésünk egy problémaorientált oktatási lehetőségeket és digitális technológiai újításokat kínáló eszközfejlesztés megalapozása a földrajzoktatás módszertani megújítására. Célunk a 8-13. évfolyamok számára alkalmazható, Magyarország egyes kis/közép tájainak, városainak földrajzát feldolgozó tanulói segédanyagok, illetve tanári kézikönyvtervezet és könyvrészlet elkészítése, melyek a tanárok számára lehetővé teszik Magyarország egyes területeinek a korábbi leíró jellegü tanítástól eltérő, problémacentrikus feldolgozását, s mintául szolgálnak más tananyagrészek hasonló módszertani megközelítésére (Pál et al., 2018).

Kutatásunk első három éve alatt kidolgoztuk a fejlesztendő eszköz (munkáltató lapok) fö koncepcióját, mely elvrendszer néhány sarokpontja a következő: kevés, ún. informatív, leíró tankönyvi szöveg alkalmazása; a tájak időbeli változásának megfigyelését, elemzését lehetővé tevő, különböző időpontokban készült, azonos méretarányú térképek beépítése; az adott táj aktuális természeti vagy társadalmi problémájának felvázolása; kapcsolódó gondolkodtató feladatok megadása; a megoldási lehetőségekhez adatsorok, forrásszövegek, grafikonok, térképvázlatok, képek stb. (változatos információforrások) megjelenítése; QR-kódokkal kiegészített linkek, interaktív, internetes feladatlapok, információk közlése; a tanári példányban járulékos, kiegészítő információk elhelyezése, módszertani ajánlások közlése.

Az elkészült munkáltató lapok honlapunkon elérhetők, kipróbálhatók, a gyakorlatban tesztelhetök, letölthetök (URL2). Fontos feladatnak tekintjük a kidolgozott eszközök tesztelését a pályázathoz csatlakozott általános és középiskolák oktatási gyakorlatában. 2019 tavaszán hat általános iskola bevonásával kísérleti és kontrollcsoportos mérést szerveztünk Magyarország témakörének tanításához (8. osztály) kapcsolódóan. A kísérleti oktatásban (ahol az általunk fejlesztett munkáltató lapok bevonásával zajlott a tanítás) 115 fö vett részt, a kontrollcsoportokban 151 tanuló. Bemeneti és kimeneti feladatlapok segítségével mértük a kísérleti csoport és a kontrollcsoport tanulási eredményességében beállt különbségeket. Az első mérések azt jelzik, hogy a hagyományos feladatoknál (topográfia) nincs szignifikáns különbség a két csoport között, az új típusú feladatoknál (például földrajzi szövegértés, gondolkodási, problémamegoldó képesség) van, a kísérleti csoport javára. Összességében a teljes teszten a kísérleti csoport átlaga szignifikánsan magasabb lett $(\mathrm{t}=3,56 ; \mathrm{p}<0,001)$, a kísérleti hatás nagyságát kifejező éta-négyzet értéke pedig 5,3\%, ami a pedagógiai kísérletek hatékonyságvizsgálatának hagyományos mérföldkövei szerint közepes kísérleti hatást jelez.

A fejlesztés jól illeszkedik a 2020 februárjában hatályba lépő földrajz kerettantervi koncepcióhoz (URL3) is, amely a 7. évfolyamon Magyarország tanítása kapcsán többek között az alábbi fejlesztési feladatokat fogalmazta meg:

- Egy-egy kis- és középtáj vagy település komplex módon, több szempontú megközelítéssel történő vizsgálata során a problémamegoldó, valamint a rendszerben és összefüggésekben történő gondolkodás fejlesztése. 
- Magyarországgal kapcsolatos földrajzi ismeretek feldolgozása során az önálló és hiteles információszerzés, valamint a felelős véleményalkotás fejlesztése.

- Véleményalkotás, logikus érvelés és vitában való részvétel képességének fejlesztése földrajzi témájú szövegekben bemutatott hazai természeti, környezeti és társadalmi jelenségekhez, folyamatokhoz, információkhoz kapcsolódóan.

Fontos feladat az eredmények minél szélesebb körben történő elterjesztése, lehetőséget adva arra, hogy azok beépülhessenek a közoktatási gyakorlatba. A kidolgozott eszközöket beépítettük az SZTE, a PTE és a DE tanárképzési és tanár továbbképzési gyakorlatába. A tanár továbbképzésben az elmúlt három év alatt négy tanár továbbképzési programot akkreditáltattunk és hirdettünk meg, amelyek mindegyikébe beleépülnek az új fejlesztés valamely (tartalmi és/vagy módszertani) elemei. A 2019/20-as tanévben az alábbi földrajz szakmódszertani tanár továbbképzések kerülnek megrendezésre: „Új eredmények a földrajzban, új szemléletű földrajzoktatás” (SZTE), „A Földrajz Új Világa” számítógép és Internet alkalmazása a földrajztanításban (SZTE), „Földrajztanítás - válogatott módszertani fejezetek” (DE), „Korszerü földrajzi ismeretek és oktatási módszerek" (PTE).

A kutatás folytatásának egyik fö irányaként az utóbbi évek megváltozott igényeihez alkalmazkodva új perspektívaként és törekvésként jelent meg az elkészített anyagok digitális tananyagként, online térben való alkalmazhatóságának vizsgálata (Bujdosó et al., 2019). Az elmúlt évben egy munkáltató laphoz (Balaton - az ezerarcú magyar tenger) minta online alkalmazást készítettünk, amely lehetővé teszi, hogy a tanulók egy virtuális térben kalandozva, az egyes információkat, interaktív feladatokat tetszőleges sorrendben felfüzve haladjanak az adott témakör élményszerü megismerésével.

A kutatás nemzetközi kiterjesztésének egyik lehetősége a földrajztanár-képzésben egy új kezdeményezés bevezetése, melyet Q-Kollegs (Q mint questions, query, qualifications) címmel hoztunk létre a Szegedi Tudományegyetem és a Humboldt Egyetem (Berlin) közreműködésével. A képzés módszertani újdonsága, hogy mindkét egyetemen a 2019/20-es tanév I. félévében párhuzamosan kurzust indítottunk földrajztanár szakos hallgatók számára a kutatásalapú módszerek elsajátítására. A kurzusra jelentkezett német és magyar földrajztanár szakos hallgatók párokat alkotva közös kutatási témán dolgoztak (téma: a határ fogalmának kutatása általános és középiskolai tanulók és tanáraik mentális térképének segítségével, valamint a földrajz tankönyvekben). A hallgatók a közös munkát a félév során mentor tanáraik (prof. dr. Farsang Andrea, prof. dr. Péter Bagoly-Simó és Verena Reinke) segítségével online kapcsolattartás (Skype) mellett végezték. A módszer jó szolgálatot tesz nemcsak az egyetemi 
képzéseink nemzetköziesítése és a tanárok módszertani kultúrájának szélesítése terén, de lehetőséget nyújt leendő tanáraink idegen nyelvi kompetenciájának fejlesztésére is.

\section{IRODALOM}

Allen, D. E. - Duch, B. J. - Groh, S. E. (1996): The Power of Problem-based Learning in Teaching Introdutory Science Courses. In: Wilkerson, L. - Gijselaers, W. H. (eds.): Bringing Problem-based Learning to Higher Education: Theory and Practice. San Francisco: Jossey-Bass, 43-52. DOI: 10.1002/t1.37219966808

Arts, J. A. R. - Gijselaers, W. H. - Segers, M. S. R. (2002): Cognitive Effects of an Authentic Computer-supported, Problem-based Learning Environment. Instructional Science, 30, 465-495. https://link.springer.com/content/pdf/10.1023/A:1020532128625.pdf

Bujdosó G. - Jász E. - Császár Z. M. et al. (2019): Virtual Reality in Teaching Geography. 12 $2^{\text {th }}$ International Conference of Education, Research, and Innovation. Sevilla, Spain. International Academy of Technology, Education and Development (IATED), 659-665. DOI: 10.21125/ iceri.2019.0215, https://www.researchgate.net/publication/338106943_VIRTUAL_REALITY_ IN_TEACHING_GEOGRAPHY

Csapó B. (szerk.) (2002): Az iskolai tudás. Budapest: Osiris Kiadó, http://publicatio.bibl.u-szeged. hu/11931/1/CsBeno_Iskolai_tudas_2002.pdf

Csapó B. (2004): Tudás és iskōala. Budapest: Műszaki Kiadó, http://www.edu.u-szeged.hu/ csapo/ publ/2004_Csapo_Tudas_es_iskola.pdf

Farsang A. (2011): Földrajztanitás korszerüen. Szeged: GeoLitera

Kádár A. - Farsang A. (2017): Comparing the Plate-tectonics-related Misconceptions of High School Students and University Undergraduates. Review of International Geographical Education Online, 7, 1, 24-47. https://files.eric.ed.gov/fulltext/EJ1157785.pdf

Kádár A. - Farsang A. - Gulyás Á. (2018): Általános- és középiskolás diákok éghajlati folyamatokhoz kapcsolódó tévképzeteinek összehasonlító elemzése/Comparative Analysis of Elementary and Secondary School Students' Climatic Related Misconceptions. Földrajzi Közlemények, 142, 3, 219-234. http://real.mtak.hu/92737/

M. Császár Zs. - Varjas J. - Farsang A. (2018): A problémaalapú tanulás alkalmazásának lehetőségei a hazai földrajzoktatásban. In: Fazekas I. - Kiss E. - Lázár I. (szerk.): Földrajzi tanulmányok 2018. Debrecen: MTA DAB Földtudományi Szakbizottság, 45-48. http://publicatio. bibl.u-szeged.hu/15739/

Pál V. - Farsang A. - Szilassi, P. et al. (2018): Developing Problem-oriented Worksheets for Expanding the Possibilities of Teaching Hungary's Geography. In: Geophysical Research Abstracts 20. Paper: EGU2018-19514, https://meetingorganizer.copernicus.org/EGU2018/EGU2018-19514. pdf

Probáld F. - Szilassi P. - Farsang A. (2015): A regionális földrajz helyzete a magyar felsőoktatásban. Földrajzi Közlemények, 139, 1, 43-53. http://real.mtak.hu/23697/

URL1: https://mta. hu/tantargy-pedagogiai-kutatasi-program/mta-szte-foldrajz-szakmodszertani-kutatocsoport-107239

URL2: http://foldrajzmodszertan.hu/

URL3: https://www.oktatas.hu/kozneveles/kerettantervek/2020_nat 